\title{
Higher Education for Professional and Civic Values: A Critical Review and Analysis
}

\author{
Kerry Shephard *(1) and Tony Egan \\ Higher Education Development Centre, University of Otago, Dunedin 9054, New Zealand; \\ Tony.Egan@otago.ac.nz \\ * Correspondence: Kerry.shephard@otago.ac.nz; Tel.: +64-3-479-8439
}

Received: 31 October 2018; Accepted: 21 November 2018; Published: 27 November 2018

\begin{abstract}
Education for sustainable development (ESD) is generally thought to involve some degree of education for particular professional and civic values, attitudes and behaviours (leading to, as examples, being environmentally, socially and culturally responsible); although it is notable that the application of ESD in higher education is contested. This conceptual article analyses literature that describes how higher education addresses professional and civic values, mindfully or unintentionally, in an attempt to provide clarity to the arguments involved in this contestation. The article uses three disciplinary lenses (education, psychology and professional education) in the context of four educational paradigms (experiential learning; role modelling; assessment/evaluation; critical thinking) to explore the theoretical and practical bases of values-education. Our conceptual analysis confirms that values are: of great interest to higher education; a significant focus within experiential learning and in the context of role modelling; but challenging to define and even more so to assess or to evaluate the attainment of. Our three disciplinary lenses also lead us to conclude that encouraging students to develop a disposition to explore their world critically is a form of values-education; and that this may be the only truly legitimate form of values-education open to higher education.
\end{abstract}

Keywords: professional education; values; attitudes; affect; values education; critical thinking; critical disposition

\section{Introduction: The Context of Values-Education in Higher Education}

As our planet, human societies and other organisms confront unprecedented challenges brought about by, as examples, human population increases, social transformation and climate change, societies look to their universities for advice, support and solutions [1]. Any broad-brush description of the roles of higher education is likely to include research (solving problems and contributing to the wealth and health of sponsoring societies), teaching (supporting the development of the next generation of creative, economically active and influential citizens, and the next generation of academics) and service (incorporating diverse functions in support of society) [2]. In some cases, service, or the third mission, specifically includes the role of 'critic and conscience of society' within which universities are expected to guide their sponsoring societies and to comment if these societies deviate from what the university, and its academics, think acceptable behaviour [3]. This third mission introduces complexity to the roles of higher education, as all of its functions are to a degree in service of society, and all no doubt interact, but only the third mission specifically emphasises some element of directing or correcting society. For readers of this journal, universities that have chosen to educate their students 'for sustainable development', or 'for environmentally responsible citizenship' provide a particularly striking example of where teaching is designed to contribute to societal direction or correction in the future.

This 'critic and conscience of society' role is specifically allocated to tertiary institutions in some countries (for example in New Zealand, New Zealand Education Act, 1989) and similarly supported 
by prescribed academic freedom for institutions and their academic staff and students. As described by Jones, Galvin and Woodhouse [4] " ... universities have a responsibility towards society, to work for what they view as the good of society, even at the cost of passing judgement on aspects of that society". Considerable academic discourse is focused on the central function of academic freedom in support of this role (see for example, Akerlind and Kayrooz) [5]. Academic work in these contexts inevitably interacts with the values, attitudes and behaviours of particular societies, and in some cases, of particular elements of societies, and of student groups [4]. In all situations we might expect congruency between the values-based messages provided to society and those provided to students.

Although values-education sits uncomfortably with a liberal view of education, there are some examples of higher-education teaching, research and service activities that do address values, attitudes and behaviours and appear to do so in an open, and widely supported, manner. Professional schools within our universities almost universally aim to influence the developing values (sometimes styled as attitudes or attributes, or indeed as 'professionalism') [6] of our students to align with those of the professional body involved. More generally, our institutions emphasise academic integrity within our educational programs and many include worthy values in their lists of graduate attributes that are fostered institutionally (often specifying what graduates will respect, or have commitment to, or appreciate). Our own New Zealand institution, for example, attempts to foster in our students a global perspective, cultural understanding and certain aspects of social responsibility. Similarly, the Association of American Colleges and Universities [7], for example, identifies "Character traits associated with the five dimensions of personal and social responsibility" which lists traits associated with each dimension together with a justification. And many hundreds of higher education institutions around the world have signed the Talloires Declaration, promising to 'educate [our students] for environmentally responsible citizenship' (Association of University Leaders for a Sustainable Future) [6]. These forms of values-education do not solely exist within our institutions for the benefit of our students; they also extend outwards towards our societies. Along the same lines: our science communicators wish to change the way that society values science; our epidemiologists encourage citizens to value vaccination; our nutrition experts encourage us all to value healthy diets and exercise.

In this context, academic activities could be understood as attempts by a few to change the values, attitudes and behaviours of many in society; of course, always for the good of society as comprehended by the academics involved. Alternatively, they could be understood as simply maintaining the status quo, either deliberately or through lack of conscious engagement. And apprehension about the nature and need for change could be legitimised by the complexity and comprehensiveness of higher education's role. A judgement, for the good of society, based in research, may be put to effect through teaching, for the good of society, and rationalised through higher education's service, critic and conscience, role. Indeed, the notion of universities 'working for the public good' is widespread in higher education discourse, albeit shifting with time [8]; and is in some respects reinforced by changing conceptions of students' place within higher education; increasingly, in some cases, as consumers, rather than as partners [9-11].

It may be that higher education imposes its own limits on its actions and that indeed these limits are reinforced by its own academic freedom to do so; perhaps particularly in choosing what and how to teach in the context of values-education. Some higher education teachers avoid, at all costs, charges of indoctrination [12] or politically inspired education [13]. Others reflect on the perils of values-education, for example in the context of education for sustainability [14]. Much of this discourse converges on the need for learners in higher education to develop critical aptitudes, or dispositions [4], autonomous thinking [15]; or as the New Zealand Education Act, 1989, puts it 'intellectual independence' and for learners to uncover the inevitable power relations in discourse (see for example, Foucault, as described by McHoul and Grace, [16]). Newman (1907) optimistically characterised the university as an institution that promotes intellectual self-empowerment [17]. In this context and with respect to critical thinking, Shephard (2015) argues; "Above all, students in higher education need this ability, attribute or disposition to fully understand what they are being taught in higher education" ([4], p. 43). 
This article uses a conceptual process [18] to review the literature that explores the means by which higher education around the world addresses values-education, mindfully, or unintentionally. The article initially situates values within the broad theoretical structure of learning and teaching. It then uses three disciplinary lenses (education, psychology and professional education, as all three offer discipline-specific insights into values-education), in the context of four educational paradigms (situated/experiential learning, role modelling, assessment/evaluation, critical thinking, as all have specific relevance to values-education), to explore the theoretical and practical bases of values-education. The article ends by exploring the premise that encouraging students to develop a disposition to explore their world critically is a form of values-education; and that this may be the only truly legitimate form of values-education open to higher education.

\section{Situating Values-Education within Learning and Teaching}

Higher education has in recent decades progressively moved away from being underpinned by behaviourist learning theories (emphasising positive reinforcement for 'getting the right answer') to constructivist learning theories (emphasising the need for learners to build their own mental models of their learning). Constructivism is a broad framework applied to thinking and learning emphasising the active part played by the individual in developing concepts and ways of thinking that can be used in daily life and in communicating with others. Theorists as diverse as Dewey, Piaget, Kelly and Bruner have all contributed to constructivist ideas. Constructivist approaches to learning aim to connect new knowledge and ideas to existing knowledge and ideas resulting in the elaboration of cognitive structures that are personally meaningful and interconnected. The implications of this are both subtle and powerful. For example, memory is seen less as a filing system out of which replicas of some past event can be drawn and more as a reconstruction of a past event open to the influence of the original context and personal beliefs, thoughts and emotions extant at that time or arising subsequently. The emphasis is, therefore, on the construction of meaning for the individual; granted that it may be socially influenced and reflective of societal and learner's values.

At the heart of constructivism is the idea that our learning starts somewhere, with a personal picture, or mental model, of something; and that teaching and learning helps learners to progressively adapt and build their personal picture, perhaps along the lines suggested by their teacher or maybe in a totally different direction, and likely results in changes to a learner's original model. Either way, building on, around, or away from what comes before is a key concept within: Dewey's anti-foundational teaching ideas (suggesting that learning works best when a learner's prior conceptualisations are challenged by new experiences [19]); Vygotsky's Zone of Proximal Development (suggesting that learning occurs in relation to what can be achieved unaided, and what can be achieved with support; see for example [20]); and Kolb's experiential learning theory (suggesting that learning involves learners reflecting on concrete experiences; [21]). Kolb's cycle of learning progresses from an initial experience (including perceptions and feelings) to reflection (including recall, analysis and questioning) out of which meaning (of the experience) is derived/interpreted giving rise to new conceptualisations (reconstruction, elaboration of earlier meaning, creation of new meaning) that may then be applied or tested with experiences in new situations. Typically, reflection takes place after the experience (reflection-on-action) although reflection can take place during an experience or activity (reflection-in-action, a form of self-monitoring). Schön refers to both forms of reflection, identifying reflection in action as a mark of connoisseurship [22].

Most of these ideas or theories of learning implicitly incorporate learners' values as part of the learning process, but some explorations have specifically identified domains of learning, separating out values as affective and different from knowledge and skills that are cognitive in nature. With respect to learning values, rather than knowledge or cognitive skills, the need for learners to identify, describe and challenge their own values is explicit within Krathwohl and Bloom's affective hierarchy (see for example, [23]), and within a broad range of transformational learning theories based around critical reflection including that of Mezirow [15]. Krathwohl and Bloom's affective hierarchy identifies listening, 
responding and valuing as the first three steps on the affective hierarchy, and the role of teachers in this learning as that of providing situations in which these affective attributes are systematically, and sequentially, learned. Two subsequent steps on the affective hierarchy involve organising and characterising value-compatible actions or behaviours, which together may be identified as having a disposition, inclination or tendency to act in a particular way, or a particular personal identity.

Scriven (1966) identifies a range of values that are themselves necessary for learners to acquire in order to attain some higher-order cognitive outcomes [24]. For example, he argues that scientists do need to value 'objectivity' to succeed as scientists. In the context of 'higher education for sustainability', Shephard argues that any education 'for' sustainability (as described, for example, by Agenda 21 requiring changes in societal attitudes; United Nations Conference on Environment and Development, 1992) is essentially a quest for affective learning outcomes [25] and that Krathwohl and Bloom's affective hierarchy provides educators with a tool to help them to decide how far up the hierarchy they are willing to teach. Educators wishing to change students' values, attitudes, worldviews, identities or dispositions, are teaching at the highest level of the affective domain.

\section{Experiential Learning}

All learning is experiential in some sense. In educational settings experiences can range from lectures and tutorials to laboratories, workshops, role-plays, field trips, practice placements (or immersion) and in-service training. In this context, experiential learning situated within an authentic learning environment where values are embodied may be expected to be particularly relevant to values-education. Similarly, the idea that 'what is being addressed' in higher education needs to, in some way, resonate with those learners who are 'being taught', is arguably a fundamental tenet of educational practice. The idea has links to motivation, relevance and power within educational discourse and may have particular linkage to values-based education. Box 1 explores experiential learning in values-education through three disciplinary lenses.

Box 1. Experiential learning and values-education.

It is fair to say that emotions, attitudes and values are characteristics that education generally, and higher education specifically, have found challenging to address. The affective domain of Bloom's taxonomy has probably been the least used in education planning and research. With respect to experiential learning, Gable and Wolf (1993) suggested that prior to the 1970s education considered affective-domain objectives to be more appropriately left to the family home or to religious institutions to address [26]. More recent educational interest in behaviours (such as 'environmentally responsible citizenship') as educational outcomes has renewed interest in links between values, behaviour and education.

One of the most influential psychological theories attempting to relate attitudes and values to actual behaviour is the theory of planned behaviour (Ajzen 1985, [27]) derived from Fishbein and Ajzen's 1975 theory of reasoned action. These theories combine constructs of personal attitudes and experience of norms to explain and predict the individual's intention to behave in a particular way. The more recent inclusion of the construct 'perceived behavioural control' was largely a response to Bandura 's concept of self-efficacy, an important construct in social cognitive theory [28] and a strong link to teaching and learning.

Many professions include workplace experiences as part of professional education; as examples, medicine, nursing, physiotherapy, law, architecture, engineering and teaching. Professional education in universities usually specify the attitudes and values that are considered to characterise the profession in addition to the knowledge and skill base that constitute its claim to be a profession. In such cases graduate profiles and educational objectives will include attitude- and value-related qualities with the aspiration that these will be internalised as individuals develop a 'professional identity'. Workplace experiences (or simulations thereof) frequently provide the basic ingredients of for the development of professional identity: "Socialization is the key period within which individuals begin to form identification with their profession as they internalize the norms, values, behaviours and attitudes expected of their new roles." (Caza and Creary, 2016, p. 9). Referring to Becker's earlier sociological research on the medical profession, the authors comment: "In fact, some researchers have even theorized that the informal curriculum medical residents are exposed to during socialization may overpower some of the more technical 'official' curriculum" ([29], pp. 9-10). The implication is that developing a professional identity is at least in part a function of social influence resulting from immersion in a professional culture and that the result may or may not align with the formally prescribed attributes of the profession. 
Box 1. Cont.

The principles of legitimate peripheral participation provide a good theoretical basis for structuring the workplace experiences of novices (Lave and Wenger, 1991, [30]). One of the challenges facing novices in professional courses on their journey to full participation in practice is their status: are they students or are they professionals? It seems unlikely that realization of their professional role occurs at the point of graduation, for some it may be earlier, for others it may be later and for some it may never occur. With reference to the nursing profession, Dall' Alba comments "While knowledge and skills are necessary, they are insufficient for skillful practice and for transformation of the self that is integral to achieving such practice. When we concentrate our attention on epistemology —or what students know and can do —we fail to facilitate and support such transformation." ([31], p. 1). This points out the crucial role of affect within the transition or transformation of identity that takes place as students traverse the threshold from layperson to professional.

Similarly, medical students can struggle with feelings that they are pretenders when engaging with real patients in a clinical context. They may be attempting to reconcile their inner world (uncertainty about their legitimacy and competence) with their perception of the role of the doctor (built up from exposure to curriculum ideals and numerous examples of confident practicing clinicians). Their dilemma can be expressed as 'performing to a prescription' as distinct from 'acting authentically' with the implication that their overt behaviour may be the result of situational factors (meeting faculty expectations) rather than personally motivated by factors such as their knowledge, skills and professional attitudes and values. Achieving a balance between professional and situational influences and personal motivations is one of the challenges in developing a professional identity [31-33]. Reflection on critical incidents, or experiences, has become an important tool in professional education for promoting learning based on experience. Our own institution uses TPERs (Thought Provoking Episode Reports) designed to enable students to explore their experiences, in relation to their perception of their own developing values and emerging identity as a professional.

It is also notable that much professional education involves the use of case studies. These may be paper-based, on-line, simulations (varying in realism) or work-based (practical, authentic). For example, in health professional education Thistlethwaite and colleagues identified 104 eligible published research papers for inclusion in a systematic review of the use of case-based educational methods across a range of health professions [34]. There are a number of ways in which such case-based explorations may be further processed individually including reflective essays, critical incident descriptions, journaling, and the use of personal portfolios. Such individual exploration may also be subject to faculty or peer feedback via group discussions. All of these experiences have the potential for illustrating, implying, exposing or invoking a variety of attitudes and values, which may or may not be addressed directly. Defining the values and attitudes that constitute the learning objectives for undergraduate education in medicine has become commonplace and relatively straightforward. Facilitating their achievement and integration into a fluid performance as a professional has proved more challenging and has led to explorations of the concept 'professional identity' as an embodiment of professional performance.

The literature included in Box 1 suggests that experiential learning opportunities will, intentionally or otherwise, expose students to values, attitudes and behaviours that may be relevant to their intended learning. Educational theorists nowadays identify that much learning occurs in social settings and build on educational psychologist's ideas that individual learning-development relates strongly to interactions between individuals in social groups and that the mental models themselves develop socially, as indeed does the knowledge. Lave and Wenger developed their model of learning in communities of practice from ethnographic studies of different workplaces, noting that each community was formed around a common purpose. Participation in the group's activities varied from peripheral to central; newcomers or novices began at the periphery and worked their way towards the centre, as necessary, in pursuit of the common purpose. The functioning of the community ideally is based on values such as trust, respect and openness, and participants in these communities ideally recognise and adopt these values as they participate. Learning in a context resembling the context in which the learning will be applied facilitates the construction and elaboration of meaning and enables transferability while core participants serve as role models. Situating learning in a workplace or community adds not only relevance and meaning to the learners' experience but also creates a connection between educators and the community within which they are placed $[35,36]$ and, potentially, realignment of the roles and responsibilities of society and university [35,37-39]. Where individuals note a particular values-based standpoint with respect to, 
for example, environmental responsibility, it is often in the context of particular experiences that yield critical incidents [40,41].

\section{Role Models}

R.K. Merton coined the term role model and linked it to the aspiration to belong to a reference group [42]. Social impact theory (Latane [43]) suggests that the more important the role model (or group represented by the role model) the greater the influence of the role model. These ideas overlap with socialisation theory (Bragg [44]) and with the broad literature on communities of practice (Lave and Wenger [30]). In general terms, and in the context of learning, the behaviours of those in a position of authority, power or with greater knowledge may have a substantial bearing on what we learn and what we learn to value. Box 2 explores the roles of role models in values-education through three disciplinary lenses.

Box 2. Role models and values-education.

In the context of education and psychology, professed values may be 'evaluated' by learners against actual behaviour (does the walk match the talk?). Lack of alignment has given rise to concepts such as 'the hidden curriculum' and the 'informal curriculum' [45]. At the level of individual experience, awareness of a discrepancy between professed values and behaviour can create cognitive dissonance [46] and the motivation to reduce it, generally by altering either behaviour or beliefs, by changing some combination of the two or by reducing their importance. From a learner's perspective, a discrepancy between a teacher's professed values and actual behaviour may be interpreted as lip service, hypocrisy or as a sign that values don't apply in practice [47]. One study based in New Zealand suggested that the most favoured strategies for teaching values included teacher role-modelling [48]. The strategy appeared to work best when teachers were confident in their ability to role-model particular values but less effectively when teachers questioned some of their own values and ability to role-model these values. Higher education is currently perplexed about its role in promoting integrity in its students. Relevant debates address plagiarism and data fabrication in research. Bertram-Gallant describes academic integrity as a "learning and teaching imperative" ([49], p. 1). Research by Löfström, Trotman, Furnari and Shephard emphasised that some, perhaps many, university teachers regard role modelling the value of integrity to be the only approach that they would feel comfortable being involved with [50]. Others felt far more able to teach the value of integrity more directly. Similar levels of confusion exist with respect to a range of values related to caring, for patients, for people in other countries and for the environment. Fien makes a strong argument that education cannot be neutral. If it does not actively promote change, it is de facto supporting the existing social order [51].

In a recent systematic review of teaching professionalism in medical education [52] role modelling, in conjunction with personal reflection, was identified as an important way in which professional values are learned. When a novice observes a competent performance by a senior colleague, that performance may become a personal goal to which the novice aspires. Learning from the observation of a consummate performance creates the conditions for the internalisation of the values implicit in that performance and their potential to serve as intrinsic motivators in professional practice. The reflective process plays a key part in identifying and articulating values that can then be analysed, evaluated and incorporated into a learner's personal belief system that supports behavioural intentions.

While there is little doubt about the power of role modelling in supporting, and directing the learning of values, there is considerable disagreement within the higher-education teaching profession about who should be role-modelling values, which values should be role-modelled and how learning actually develops from role models. Borgstrom et al. found that final-year medical students experienced role models representing two value sets simultaneously; an older model of professionalism (interpreted by some as 'doctor knows best') and a new value set that emphasised holistic care and patients' rights to have their say in their care [32]. These researchers discovered that the new values did not simply replace the old values and students had to manage the tensions that arose when they experienced role models and practices demonstrating values from both old and new sets. Whereas the new values were open and clearly communicated in institutional documentation, the older values tended only to emerge in clinical practice. The authors concluded: "As a result, professionalism does not consist of a set of fixed or abstract concepts, but rather surfaces through medical practice." ([30], p. 1335). Consequently 'official' and 'unofficial' values may have influence on newcomers to a particular clinical environment. Paice et al. [53] emphasised that if institutions do not want unofficial values to find their way into the actual curriculum, they need to find ways to raise awareness of 'good' and 'bad' practices, to address the visibility of poor role models and encourage reflection on the range of behaviours observable in clinicians at work. 
The literature included in Box 2 suggests that much depends on which particular values are being modelled. Shephard [3], for example, suggests that most of his academic colleagues do not plagiarise or fabricate research data and that where they teach professional values such as honesty, integrity and respect within professional schools, they role model these same professional values themselves. These values are widely accepted and role modelled by most professionals outside of academia so that when graduates leave the institution these values are reinforced. Problems arise when professions change their values (as described by Borgstrom et al. [30]), when university teachers profess values that they do not share themselves, such as, in some cases, sustainability values, or when graduates move from universities to wider society and discover that the values taught in the university are not shared more widely [3].

\section{Assessment and Evaluation}

At some point any reasonable discussion about values-education must address concepts described variously as assessment and evaluation. [In most countries where the authors have resided and researched, assessment relates to individual learners and generally results in some form of numerical or alphabetical score or ranking applied to these individuals. Evaluation is then a broader concept relating primarily to the educational institution, or programme or particular teachers, and tends to ask questions about the nature of the educational process involved rather than about the achievements of the individual learners involved. The two terms are used in different ways in some countries.] Whatever we are educating for, including education for particular values, we will be interested, as educators, in the extent to which our educational efforts have resulted in learning. Box 3 explores assessment and evaluation in values-education through three disciplinary lenses.

Box 3. Assessment, evaluation and values-education.

Within the discipline of education, teachers are likely to agree that assessment and evaluation in the context of values-education is more challenging than it is for education focused on cognitive skills. Values are often viewed by those being educated as personal rather than as public and by educators (in the context of teaching them) as something to be avoided, along with accusations of indoctrination [12]. And as described in previous sections of this article, it is not always easy to ascertain when values are actually being learned and whether those values being learned are the same as those values intended to be taught by the teachers concerned. Bloom, Hastings and Madaus do not underestimate the challenges involved in assessing learning in the affective domain but do provide teachers with research-based advice on how to do it, with particular reference to an emphasis on learners progressing up the domain's hierarchy [11]. Teachers' observations and subjective judgment provide the mainstay of assessments on lower steps in the hierarchy (confirming for example that students are prepared to listen, or to respond, in given circumstances). Further up the hierarchy more objective assessment generally requires students to respond directly. Attitude surveys provide important contributions to assessment of the values and attitudes held by students but come with the difficulty that, in effect, students are self-assessing. Self-assessment is identified as particularly problematic when the values being assessed are in some senses sensitive for those concerned. Acquisition of many of the values being considered here, and with respect to qualifications, grades and future employability, ensure that much within this discourse is 'sensitive'. Bloom et al. [11] recommend that attitude surveys can be used in these circumstances if students are anonymous in the process and where the assessment is with respect to the cohort rather than to the individual. There is an expanding body of research encouraging anonymity in assessment in situations involving sensitive questions [54], subjectivity and halo bias [55] and social-desirability response-bias [56].

Much of the previous paragraphs address what learners might choose to do with the knowledge and skills that they learn. In this context, knowledge and skills are cognitive, while learner choice is moderated by affective, emotional characteristics of the learner, perhaps in combination with other factors (as predicted for example, by the theory of planned behaviour [27]). The discipline of psychology has of course contributed to all of these ideas in some ways, but is also responsible for other ideas about what motivates learners to act on what they learn. Conation is a term no longer widely used in psychology, but essentially and usefully addresses how learners learn to be motivated to act, and how teachers can teach motivation. Snow and Jackson helpfully described how conative constructs could be assessed or evaluated [57]. 
Box 3. Cont.

Assessment, or evaluation, of the attainment of identified values is practised in much of professional education. Our teachers, lawyers and medical practitioners all identify particular values as outcomes of professional education and make considerable effort to assess or evaluate their attainment. Also, although historically many professions have developed lists of values, nowadays it is more common for professional groups to specify the kinds of behaviours that stem from particular value-bases [3]. One approach widely used by medical schools to assess individual behaviours is the OSCE (Objective Structured Clinical Examination) where, typically, students are exposed to actors pretending to be patients, and university teachers, as assessors, watch and listen as the student performs the required tasks. As assessors, and as knowledgeable educators, of course, we are concerned to separate a student's ability (based on a sound knowledge base) to demonstrate a required behaviour, from that student's deep-seated values-based disposition to perform in that particular way in future. As suggested by Bleakley (2011), for example, "In focusing all of our resources upon finer and finer detail in the psychometrics of the OSCE, we have forgotten that the OSCE can be seen as a piece of theater in which roles are scripted. We can then analyze the OSCE sociologically for its performative, rather than psychometric, dimensions and this reveals some uncomfortable possibilities, such as medical students 'faking it'." [58] (p. 231). As with so much in education when we are exploring the details of learning, we need to ask in detail what types of learning are involved. If as educators we are happy that having the knowledge to do something and the skills to do it is enough, then observing the fact that the student is actually able to do it is also enough. Whether or not it is important that medical students may or may not be faking it does depend on the fine detail of the learning required.

Professional educators are, of course, not naive to these possibilities. Many professions have been confronted by society's objections to rogue professionals who have passed all of their professional examinations but subsequently exhibited un-professional behaviours (see for example, the analysis by Jones, McCullough, and Richman, on who should be held responsible for doctors who behave unethically [59]). Professional educators use a diversity of approaches to filter potential wrongdoers out of the system before they graduate, but the difficulties associated with formally assessing, or examining, affective outcomes do produce challenges and likely result in a focus on subjective, rather than objective assessment $[60,61]$. Letters of reference, provided by university teachers to graduates' prospective employers, have historically provided one means whereby subjective judgement has influenced a graduate's employability [60]. There is an expanding literature on clarifying the nature of, and developing ways to assess, the affective elements of professional competence in learning areas such as caring and respect [62], corporate and social responsibility [63,64] and environmental attitude [65].

The literature included in Box 3 suggests that although values, attitudes and behaviours are of great interest to higher education, they are challenging to assess or to evaluate the attainment of. With so much invested in teaching values, through situated and experiential learning in particular, and through the judicious involvement of role models, it must seem strange to those outside of higher education that so much learning in this field is aspirational, rather than assessed, or evaluated.

\section{Critical Insights into Values Education}

We move on from our previous sections, therefore, in some disarray. Clearly experiential learning opportunities impact on the affective characteristics of learners, and clearly role models are influential in this regard, but there is considerable disagreement within the higher education teaching profession about who should be teaching values, which values should be taught, and about how learning should be supported, assessed and evaluated. Although the paragraphs above, in general, promote the idea that learning in higher education can contribute to values-education in the context of social good, it is also the situation that some academics wish to teach values that are not necessarily endorsed by their colleagues, departments or institutions (see for example [66] in the context of sustainability). There is, in particular, an expanding discourse on the hidden curriculum that suggests that some academics may teach values without realising it, or deliberately hide the values that they hold dear (and therefore teach) but that may not be seen as acceptable by their peers [3].

An influential article published in Nature in 2014 [67] suggested that science students in higher education might become progressively less interested in the social implications of their science as they progress through their studies. It may be that the experiences gained by students during their studies, situated within the context of current science-based higher education, and of the visible and hidden curriculum, contribute to a range of relatively negative values with respect, for example, to social 
and environmental responsibility. The idea is not new. Berberet (1989), for example, suggested that education has played a key role in perpetuating unsustainable environmental practices: "Not only has education uncritically accepted the association of progress and the unfettered growth economy, it has trained the engineers and managers, performed the research, and developed the technologies which in aggregate have had such a devastating impact on the environment." (cited by Fein 1993 [68], pp. 4-5). Even within the domains of professional education, where professional values are identified and fostered and their acquisition assessed (or evaluated), there remains doubt about higher education's ability to ensure that graduating professionals actually have these values; or rather can, in a lesser way, behave as if they have. In some respects, therefore, the enterprise of values-education in higher education may have lacked critical insight and indeed may be inherently flawed.

\section{Critical Thinking}

One higher education outcome that appears to be universally valued is critical thinking (variously defined and modelled also as, for example, critical reflection). Most definitions of critical thinking emphasise that although it is often described, and conceptualised, as a skill or ability, it is itself inherently values-based. Edward M. Glaser (1941), for example and at an early stage in the development of the concept, proposed that the ability to think critically involves an attitude of being disposed to consider in a thoughtful way the problems and subjects that come within the range of one's experiences, knowledge of methods of logical enquiry and reasoning, and some skill in applying those methods [69]. More recently Scriven and Paul (1987) suggested (with clear linkages between cognitiveand affective-domain learning) that "Critical thinking is the intellectually disciplined process of actively and skilfully conceptualizing, applying, analyzing, synthesizing, and/or evaluating information gathered from, or generated by, observation, experience, reflection, reasoning, or communication, as a guide to belief and action. In its exemplary form, it is based on universal intellectual values that transcend subject matter divisions: clarity, accuracy, precision, consistency, relevance, sound evidence, good reasons, depth, breadth, and fairness." [70]. This broad range of 'universal intellectual values' is nowadays finding its way into the pedagogy of higher education, with effort underway to promote its teaching, support and assessment [71,72]. Box 4 explores critical thinking in values-education through three disciplinary lenses.

Box 4. Critical thinking and values-education.

\footnotetext{
The quest for critical thinking is associated with many levels and places of education, from primary schools to universities. For some it is an automatic extension to the idea that learning needs to be about more than information and knowledge, but should lead to higher-level cognitive skills and indeed to critically inspired behaviours. For Barnett [73] criticality has three forms: reason, reflection and action. 'Critical reason' is oriented towards formal knowledge, 'critical self reflection' is directed at the person and 'critical action' involves engagement of the person with the world. More generally, skills in critical thinking and critical reflection are commonly encountered but often poorly defined intended-outcomes from education. One attribute that underpins many of these ideas relates to an ability to analyse and reflect on the assumptions that underpin a particular aspect of thinking. Mezirow proposed three forms of reflection; content, process and premise, with the latter involving the highest degree of criticality [15]. Using this tripartite model highlights the role of assumptions, preconceptions and values that we bring to any situation or event upon which we reflect (by choice or otherwise).
} 
Box 4. Cont.

Critical reflection may be a special form of critical thinking, associated with processes of critically thinking about a particular experience. In an educational sense, critical reflection is what we encourage our students to do after they've had a potentially important experience. But as with critical thinking, we may need to teach students how to do it. Ash and Clayton situate critical reflection within the broad educational domain of experiential learning [71]. In Ash and Clayton's model, the critical reflection processes emerge as desired learning outcomes that can be planned for by university teachers. Critical reflection, identified in this way, becomes an intended outcome in its own right and a pathway to more complex learning outcomes. An important element of this form of experiential learning is that learners are exposed to experiences, such as during community engagement incorporating service learning, volunteering and some forms of overseas experience, as these experiences generally provide anti-foundational aspects of learning on which reflection can occur. Dewey emphasised that thoughtful deliberation required situations where learners had to "endure suspense and to undergo the trouble of searching ... to sustain and protract [a] state of doubt" ([19], p. 16) to become a thoughtful and educated citizen and these anti-foundational ideas have come to be seen as underpinning critical reflection. In addition, it appears likely that the nature of learning often sought in, for example service learning, is values-based. Shephard suggested that "Those who propose and support service learning hope that their students will not only learn about, for example, the struggles of disadvantaged citizens, but also develop values, attitudes and dispositions that may in the future help them, as citizens or leaders, to do something about them. There is an inherent interplay between educational approaches that focus on experience, higher order cognitive learning, the development of critical reflection skills, and affect." ([3], p. 77).

From an educational perspective, processes of critical thinking may be essentially generic processes. Analysing the assumptions that belong to one sphere of interest may involve detailed knowledge of that area, but the processes involved in the analysis may be common to other areas as well. As many of the mental attributes related to critical thinking are probably blind to the problem at hand, the immense body of knowledge and interest in problem-based learning, for example, may help us to understand how to build critical thinking skills. Critical thinking involves (on the cognitive side) analysis (of arguments), application (in the use of inductive and deductive reasoning), creativity (or synthesis, in solving problems) and evaluation (in making judgements). And on the affective side, critically thinking learners are characterised by a wide range of dispositions, attitudes or habits of mind such as being open- and fair-minded. For example, Facione [74,75] asserts that critical thinkers need to be willing to reconsider. Perkins, Jay and Tishman subdivide dispositions themselves, including the disposition to open-minded thinking, into abilities, sensitivities and inclinations [76]. Critical thinking is not necessarily easy or habitual. It takes effort. On how to teach critical thinking, Lai (2011) summarises; "If teachers are to be successful in encouraging the development of critical thinking skills, explicit instruction in critical thinking needs to be included in the curriculum, whether that instruction occurs as a stand-alone course, is infused into the subject matter content, or both" ([77], p. 43). Some researchers (such as Gokhale, [78]) emphasise the advantages of collaborative learning, stressing the important contribution that social interactions have for cognitive, and affective, development; drawing heavily on the ideas of Piaget and Vygotsky, but linking also with Krathwohl et al.'s assertions about the need for learners to listen, and to respond, and to practice their value judgements, generally in social settings, and to progress up the affective learning hierarchy with respect to the learning task at hand.

Arguably the discipline of psychology is itself a product of critical thinking in that it consists of forms of inquiry into human thought and behaviour that attempt to analyse and evaluate the origins of these phenomena. Different schools of psychology have approached the task in different ways (e.g., structuralism, behaviourism, humanism) but all make use of processes such as analysis, synthesis and evaluation. A critical disposition seems to be fundamental to most psychological theorising and practice. Research in experimental psychology, for example, has revealed that learning and remembering are not simple outputs from simple inputs. Perception is not a simple representation of an external reality but is influenced by past experiences and future expectations in making sense of the perceived world. Our understanding of phenomena such as social conformity and cognitive biases and processes such as subjective validation and selective attention has grown out of the critical analysis of human thought and behaviour and its investigation by psychologists using experimental methods in controlled, laboratory conditions. Our impression is that relatively few tertiary level psychology courses teach criticality explicitly but critical thinking is frequently encouraged and practised, particularly in the context of methodologies used in psychological research [79-81]. 
Box 4. Cont.

Critical thinking and reflection also appear to be essential elements of many professions and are emphasized in professional education [52,82]. The use of TPERs (Thought Provoking Episode Reports) or critical incident reports is common for these purposes and designed to promote a disposition towards critical reflection. It is widely reported that briefing and de-briefing experiences (such as those provided by feedback and feed-forward teaching and mentoring approaches) are important to developing professional attributes (see, for example, [6]) and an essential contribution to developing critical thinking skills [52]. A common finding from reflective exercises following practical experience, in the health professions for example, is that students question their career choice and professional identity as they compare practice with either their own ideals or the values espoused by the organisation housing the practice. With reference to the practitioner, and identity, Dalla' Alba and Barnacle suggests "This 'who' is not reducible to skill, quality or capability. It is an orientation-a way of being-in-the world as available to uncertainty and unpredictability ... know-how in professional practice needs to extend beyond knowledge and skills to who we are, as professionals." ([33], p. 1462).

All three of our disciplinary lenses, of education, psychology and professional education, suggest that critical thinking and reflection are themselves closely connected to values and affect. A critical disposition is itself a necessary prerequisite for critical thinking, and the act of critical thinking guides the beliefs and actions of those who possess these faculties (noting that in professional education, the term 'professional identity' is most likely to be used to address beliefs and actions). With respect to the general concept of values-education, it is possible that conventional educational practices, in particular through exposure to role models, do form the basis for the effective learning of values. The inclusion of criticality here has a particular function and one that is most apparent at the level of higher education. How are learners to identify which values to learn, from the diversity of educational experiences and of exposure to role models? As educators, we assume that students will not acquire values uncritically. As educators, our challenge is to understand not only the processes by which critically thinking learners use their skills to decide on the values important to them, but also the processes by which learners learn their disposition to think critically.

In this regard there is a sense in which the value-base of critical thinking is antithetical to the teaching of those values in and by higher education that are designed to lead to particular behaviours. Critical thinking, as described by Scriven and Paul, and as conceptualised by many others, provides each learner with his or her own 'guide to belief and action'. Institutional and professional bodies that demand that students graduate with particular manifestations of 'respect' or 'appreciation' or 'commitment' are in this sense denying the students' values-based application of clarity, accuracy, precision, consistency, relevance, sound evidence, good reasons, depth, breadth, and fairness to reach their own conclusions about what they will respect, appreciate or show commitment to.

\section{Discussion}

Values-education has strong bases of understanding in the disciplines of education, psychology and professional education. It also underpins the ethos of learning and teaching, and of community engagement, within the broad context of universities acting for the 'good of society'. It is possible that aspects of values-education are increasingly expected by societies as they confront unprecedented 21st century social and environmental calamities.

And yet simultaneously, higher education appears to embrace criticality as product of higher education and as a tool for education. Assuming that critical thinking is indeed centred on one or more value-based dispositions, and that higher education, in general, wishes to support learners to develop a critical disposition, it seems essentially illogical for higher education to undertake any other form of values-education that does not directly support critical thinking. Critical thinkers will use their own critical dispositions and skills to develop their own values to guide their own beliefs and to take responsibility for their own actions. In the process they will challenge the values provided to them by their upbringing and by their education. 
This analysis suggests that higher education confronts a fundamental tension. Institutionally endorsed values-education designed to direct learners towards particular ways of thinking, and towards particular values-based behaviours, appears both inappropriate, if implemented alongside education for critical thinking, and wasteful of effort. Indeed, values-education not targeted at critical thinking may only be compatible with a higher education that does not itself value critical thinking. We explore this tension in a brief discussion between a professor and her student.

Student to Professor; "So what you are saying is that you expect me to develop a critical disposition that will guide my own beliefs and behaviours; but that actually you don't trust me to do this, so instead you insist that I adopt this long list of your values, that will guide my behaviours if my own learning points me in the wrong direction."

Professor to Student; "Put like that it doesn't appear to be particularly sensible."

On the contrary, and in defence of our struggling professor, our analysis suggests that if higher education does decide to endorse only that part of values-education designed to support students to develop their own critical disposition, it need not be disinterested in the values that its academics teach or in other respects display, or in the additional values that its students develop. This analysis encourages higher education to be responsible for the cognitive and affective support likely to develop a learner's critical disposition, and for exposing these same learners to bodies of knowledge and to role models and experiences upon which their critical skills and values can be practised.

Professor to Student; "So, we would rather say that as educators, we shall do our best to provide you with experiences that will help you to develop a critical disposition. On the way we can be clear, and critical, about the values that we value, and that broader society and the professions value; but we hope that you will use your own developing critical faculties to decide if we actually use these in our professional practice, or merely profess to do so, and to decide what you value."

Monitoring the affective values and attitudes of cohorts of students on their learning journey is not incompatible with these responsibilities and may help institutions to understand if their provisions in these regards are sufficient. Assessing the values of individual students may not be compatible with these same responsibilities. Similarly, accepting and celebrating the affective diversity of its academic staff, and local communities, may be the best way to ensure that students are exposed to role models and experiences upon which students' critical skills and values can be practised.

Professor to Student; "Although we are really interested in what you learn, and will do our best to monitor your progress, what you actually learn in higher education, and learn to value, is very much up to you."

A higher education institution that values critical thinking, in this analysis, should celebrate the diversity of values that its students are exposed to, as long as sufficient emphasis is placed on values-education for critical thinking, and sufficient monitoring is in place to ensure that this fundamental mission of higher education is on track. This analysis emphasises a pressing need for higher education to develop sound protocols for teaching and for monitoring the development of students' dispositions to think critically.

Author Contributions: Authors contributed equally to this review article.

Funding: This research received no external funding.

Conflicts of Interest: Authors report no conflicts of interest.

\section{References}

1. Association of University Leaders for a Sustainable Future. The Talloires Declaration 10 Point Action Plan; Updated Version; Association of University Leaders for a Sustainable Future: Wayland, MD, USA, 1994. 
2. Shephard, K. Higher Education for Sustainable Development; Palgrave Macmillan UK: London, UK, 2015; ISBN 978-1-349-56263-3.

3. Shephard, K.; Kim, B. Tess Guiney Researching the Professional-Development Needs of Community-Engaged Scholars in a New Zealand University. Sustainability 2017, 9, 1249. [CrossRef]

4. Jones, D.G.; Galvin, K.; Woodhouse, D. Universities as Critic and Conscience of Society: The Role of Academic Freedom; New Zealand Universities Academic Audit Unit: Wellington, New Zealand, 2000.

5. Akerlind, G.S.; Kayrooz, C. Understanding Academic Freedom: The views of social scientists. High. Educ. Res. Dev. 2003, 22, 327-344. [CrossRef]

6. Wilkinson, T.J.; Tweed, M.J.; Egan, T.G.; Ali, A.N.; McKenzie, J.M.; Moore, M.; Rudland, J.R. Joining the dots: Conditional pass and programmatic assessment enhances recognition of problems with professionalism and factors hampering student progress. BMC Med. Educ. 2011, 11, 29. [CrossRef] [PubMed]

7. Association of American Colleges \& Universities. Character Traits Associated with the Five Dimensions of Personal and Social Responsibility; Association of American Colleges \& Universities: Washington, DC, USA, 2017.

8. Williams, J. A critical exploration of changing definitions of public good in relation to higher education. Stud. High. Educ. 2016, 41, 619-630. [CrossRef]

9. Bunce, L.; Baird, A.; Jones, S.E. The student-as-consumer approach in higher education and its effects on academic performance. Stud. High. Educ. 2016, 1-21. [CrossRef]

10. Tomlinson, M. Student perceptions of themselves as 'consumers' of higher education. Br. J. Sociol. Educ. 2016, 1-15. [CrossRef]

11. Molesworth, M.; Nixon, E.; Scullion, R. Having, being and higher education: The marketisation of the university and the transformation of the student into consumer. Teach. High. Educ. 2009, 14, $277-287$. [CrossRef]

12. Bloom, B.S.; Hastings, J.T.; Madaus, G.F. Handbook on the Formative and Summative Evaluation of Student Learning; McGraw-Hill: New York, NY, USA, 1971.

13. Fish, S. Save the World on Your Own Time; Oxford University Press: Oxford, UK; New York, NY, USA, 2008; ISBN 978-0-19-536902-1.

14. Jickling, B. Losing traction and the art of slip-sliding away: Or, getting over education for sustainable development. J. Environ. Educ. 2016, 47, 128-138. [CrossRef]

15. Mezirow, J. Transformative Learning in Practice: Insights from Community, Workplace, and Higher Education, 1st ed.; Jossey-Bass: San Francisco, CA, USA, 2009; ISBN 978-0-470-25790-6.

16. McHoul, A.W.; Grace, W. A Foucault Primer: Discourse, Power, and the Subject; NY University Press: New York, NY, USA, 1993.

17. Newman, J.H. The Idea of a University: Defined and Illustrated; Longmans, Green and Co.: London, UK, 1907.

18. Grant, M.J.; Booth, A. A typology of reviews: An analysis of 14 review types and associated methodologies: A typology of reviews. Health Inf. Libr. J. 2009, 26, 91-108. [CrossRef] [PubMed]

19. Dewey, J. How We Think; Heath: Boston, MA, USA, 1910.

20. Chaiklin, S. The Zone of Proximal Development in Vygotsky's analysis of learning and instruction. In Vygotsky's Educational Theory and Practice in Cultural Context; Cambridge University: Cambridge, UK, 2003; pp. 39-64.

21. Kolb, D. Experiential Learning as the Science of Learning and Development; Prentice Hall: Englewood Cliffs, NJ, USA, 1984.

22. Schön, D.A. The Reflective Practitioner: How Professionals Think in Action; Basic Books: New York, NY, USA, 1983; ISBN 978-0-465-06874-6.

23. Krathwohl, D.; Bloom, B.; Masia, B. Taxonomy of Educational Objectives, Handbook II: The Affective Domain; David McKay Co.: New York, NY, USA, 1988.

24. Scriven, M. Student Values as Educational Objectives; Social Science Education Consortium, Inc.: Boulder, CO, USA, 1966.

25. Shephard, K. Higher education for sustainability: Seeking affective learning outcomes. Int. J. Sustain. High. Educ. 2008, 9, 87-98. [CrossRef]

26. Gable, R.K.; Wolf, M.B. Instrument Development in the Affective Domain; Springer: Dordrecht, The Netherland, 1993; ISBN 978-94-010-4614-5. 
27. Ajzen, I. From Intentions to Actions: A Theory of Planned Behavior. In Action Control; Kuhl, J., Beckmann, J., Eds.; Springer: Berlin/Heidelberg, Germany, 1985; pp. 11-39, ISBN 978-3-642-69748-7.

28. Bandura, A. Self-efficacy: Toward a unifying theory of behavioural change. Psychol. Rev. 1977, 84, $191-215$. [CrossRef] [PubMed]

29. Caza, B.B.; Creary, S.J. The Construction of Professional Identity; Electronic Version; Edward Elgar Publishing: Cheltenham, UK, 2016.

30. Lave, J.; Wenger, E. Situated Learning: Legitimate Peripheral Participation; Learning in Doing; Cambridge University Press: Cambridge, UK; New York, NY, USA, 1991; ISBN 978-0-521-41308-4.

31. Dall'Alba, G. Learning Professional Ways of Being: Ambiguities of becoming. Educ. Philos. Theory 2009, 41, 34-45. [CrossRef]

32. Borgstrom, E.; Cohn, S.; Barclay, S. Medical Professionalism: Conflicting Values for Tomorrow's Doctors. J. Gen. Intern. Med. 2010, 25, 1330-1336. [CrossRef] [PubMed]

33. Dall'Alba, G.; Barnacle, R. Exploring Knowing/Being through Discordant Professional Practice. Educ. Philos. Theory 2015, 47, 1452-1464. [CrossRef]

34. Thistlethwaite, J.E.; Davies, D.; Ekeocha, S.; Kidd, J.M.; MacDougall, C.; Matthews, P.; Purkis, J.; Clay, D. The effectiveness of case-based learning in health professional education. A BEME systematic review: BEME Guide No. 23. Med. Teach. 2012, 34, e421-e444. [CrossRef] [PubMed]

35. Gelmon, S.B.; Jordan, C.; Seifer, S.D. Community-Engaged Scholarship in the Academy: An Action Agenda. Chang. Mag. High. Learn. 2013, 45, 58-66. [CrossRef]

36. Boyer, E.L. From Scholarship Reconsidered to Scholarship Assessed. Quest 1996, 48, 129-139. [CrossRef]

37. Morrison, A. Hegemony through Responsibilisation: Getting working-class students into higher education in the United Kingdom. Power Educ. 2014, 6, 118. [CrossRef]

38. Brown, K.; Shephard, K.; Warren, D.; Hesson, G.; Fleming, J. Using phenomenography to build an understanding of how university people conceptualise their community-engaged activities. High. Educ. Res. Dev. 2016, 35, 643-657. [CrossRef]

39. Deeley, S.J. Critical Perspectives on Service-Learning in Higher Education; Palgrave Macmillan: Basingstoke, UK, 2014; ISBN 978-1-137-38325-9.

40. Horwitz, W.A. Developmental Origins of Environmental Ethics: The Life Experiences of Activists. Ethics Behav. 1996, 6, 29-53. [CrossRef]

41. Chawla, L. Significant Life Experiences Revisited: A review of research on sources of environmental sensitivity. Environ. Educ. Res. 1998, 4, 369-382. [CrossRef]

42. Thompson, W.E. Society in Focus: An Introduction to Sociology with Study Card; Allyn \& Bacon: Boston, MA, USA, 2004; ISBN 978-0-205-41365-2.

43. Latane, B. The psychology of social impact. Am. Psychol. 1981, 36, 343-356. [CrossRef]

44. Bragg, A.K. The Socialization Process in Higher Education; ERIC/AAHE Research Report, No. 7; American Association for Higher Education: Washington, DC, USA, 1976.

45. Portelli, J.P. Exposing the hidden curriculum. J. Curric. Stud. 1993, 25, 343-358. [CrossRef]

46. Festinger, L. A Theory of Cognitive Dissonance; Row, Peterson: Evanston, IL, USA, 1957.

47. Egan, T.; Jaye, C. Communities of clinical practice: The social organization of clinical learning. Health 2009, 13, 107-125. [CrossRef] [PubMed]

48. Notman, R.; Latham, D.; Angus, H.; Connor, P.; McGregor, K.; Scott, J. Integrating Values in the New Zealand Curriculum: Caught or Taught? Teaching Learning Research Initiative: Wellington, New Zealand, 2012.

49. Bertram-Gallant, T. Academic Integrity in the Twenty-First Century: A Teaching and Learning Imperative. ASHE High. Edu. Rep. 2008, 33, 1-143.

50. Löfström, E.; Trotman, T.; Furnari, M.; Shephard, K. Who teaches academic integrity and how do they teach it? High. Educ. 2014, 1-14. [CrossRef]

51. Fien, J. Learning to care: A focus for values in health and environmental education. Health Educ. Res. 1997, 12, 437-447. [CrossRef]

52. Birden, H.; Glass, N.; Wilson, I.; Harrison, M.; Usherwood, T.; Nass, D. Teaching professionalism in medical education: A Best Evidence Medical Education (BEME) systematic review. BEME Guide No. 25. Med. Teach. 2013, 35, e1252-e1266. [CrossRef] [PubMed]

53. Paice, E.; Heard, S.; Moss, F. How important are role models in making good doctors? BMJ 2002, 325, 707-710. [CrossRef] [PubMed] 
54. Ong, A.D.; Weiss, D.J. The Impact of Anonymity on Responses to Sensitive Questions1. J. Appl. Soc. Psychol. 2000, 30, 1691-1708. [CrossRef]

55. Malouff, J.M.; Stein, S.J.; Bothma, L.N.; Coulter, K.; Emmerton, A.J. Preventing halo bias in grading the work of university students. Cogent Psychol. 2014, 1. [CrossRef]

56. Arnold, H.J.; Feldman, D.C. Social Desirability Response Bias in Self-Report Choice Situations. Acad. Manag. J. 1981, 24, 377-385. [CrossRef]

57. Snow, R.E.; Jackson, D.N. Assessments of Conative Constructs for Educational Research and Evaluation: A Catalogue; National Center for Research on Evaluation, Standards, and Student Testing: Los Angeles, CA, USA, 1993.

58. Bleakley, A. Professing medical identities in the liquid world of teams: Commentaries. Med. Educ. 2011, 45, 1171-1173. [CrossRef] [PubMed]

59. Jones, J.W.; McCullough, L.B.; Richman, B.W. Who should protect the public against bad doctors? J. Vasc. Surg. 2005, 41, 907-910. [CrossRef] [PubMed]

60. Shephard, K. $e$ is for exploration: Assessing hard-to-measure learning outcomes. Br. J. Educ. Technol. 2009, 40, 386-398. [CrossRef]

61. Buissink-Smith, N.; Mann, S.; Shephard, K. How Do We Measure Affective Learning in Higher Education? J. Educ. Sustain. Dev. 2011, 5, 101-114. [CrossRef]

62. Epstein, R.M. Defining and Assessing Professional Competence. JAMA 2002, 287, 226. [CrossRef] [PubMed]

63. Bielefeldt, A.R.; Canney, N.E. Social Responsibility Attitudes of First Year Engineering Students and the Impact of Courses. In Proceedings of the 2014 ASEE Annual Conference \& Exposition, Indianapolis, IN, USA, 15-18 June 2014.

64. Ralston, D.A.; Egri, C.P.; Karam, C.M.; Naoumova, I.; Srinivasan, N.; Casado, T.; Li, Y.; Alas, R. The triple-bottom-line of corporate responsibility: Assessing the attitudes of present and future business professionals across the BRICs. Asia Pac. J. Manag. 2015, 32, 145-179. [CrossRef]

65. Hollweg, K.; Taylor, J.; Bybee, R.; Marcinkowski, T.; McBeth, W.; Zoido, P. Developing a Framework for Assessing Environmental Literacy; North American Association for Environmental Education: Washington, DC, USA, 2011.

66. Cotton, D.; Bailey, I.; Warren, M.; Bissell, S. Revolutions and second-best solutions: Education for sustainable development in higher education. Stud. High. Educ. 2009, 34, 719-733. [CrossRef]

67. Cech, E.A. Education: Embed social awareness in science curricula. Nature 2014, 505, 477-478. [CrossRef] [PubMed]

68. Fein, J. Education for the Environment-Critical Curriculum Theorising and Environmental Education; Deakin University Press: Geelong, Victoria, Australia, 1993.

69. Glaser, E.M. An Experiment in the Development of Critical Thinking; AMS Press: New York, NY, USA, 1941; ISBN 978-0-404-55843-7.

70. Scriven, M.; Paul, R. Defining Critical Thinking. Available online: https:/ /www.criticalthinking.org/pages/ defining-critical-thinking/766 (accessed on 27 November 2018).

71. Ash, S.L.; Clayton, P.H. Generating, deepening, and documenting learning: The power of critical reflection in applied learning. J. Appl. Learn. High. Educ. 2009, 1, 25-48.

72. Paul, R.P.; Elder, L. The Miniature Guide to Critical Thinking; Foundation for Critical Thinking: Tomales, CA, USA, 2001.

73. Barnett, R. Higher Education: A Critical Business; SRHE/Open University Press: Buckingham, UK, 1997.

74. Facione, P.A. Critical Thinking: A Statement of Expert Consensus for Purposes of Educational Assessment and Instruction; The California Academic Press: Millbrae, CA, USA, 1990.

75. Facione, P.A. The disposition toward critical thinking: Its character, measurement, and relation to critical thinking skill. Informal Log. 2000, 20, 61-84. [CrossRef]

76. Perkins, D.N.; Jay, E.; Tishman, S. Beyond abilities: A dispositional theory of thinking. Merrill-Palmer Q. J. Dev. Psychol. 1993, 39, 1-21.

77. Lai, E. Critical Thinking: A Literature Review Accessed; Foundation for Critical Thinking: Tomales, CA, USA, 2011.

78. Gokhale, A.A. Collaborative Learning Enhances Critical Thinking. J. Technol. Educ. 1995, 7. [CrossRef]

79. Barber, T.X. Pitfalls in Human Research: Ten Pivotal Points; Pergamon General Psychology Series, v. 67; Pergamon Press: New York, NY, USA, 1976; ISBN 978-0-08-020935-7. 
80. Nisbett, R.E.; Wilson, T.D. Telling more than we can know: Verbal reports on mental processes. Psychol. Rev. 1977, 84, 231-259. [CrossRef]

81. Ericsson, K.A.; Simon, H.A. Verbal Reports as data. Psychol. Rev. 1980, 87, 215-251. [CrossRef]

82. Lawrence-Wilkes, L.; Ashmore, L. The Reflective Practitioner in Professional Education; Palgrave Pivot; Palgrave Macmillan: Houndmills, UK, 2014; ISBN 978-1-137-39958-8. 